\title{
The Ethics of Confidentiality: Professional Duties and the Uncooperative HIV-Infected Client
}

\author{
Mindie R. Miller \\ University of Kansas
}

\section{Introduction}

The purpose of this paper is to discuss the ethics of confidentiality in the professions. Each profession has its own policy regarding confidential communications outlined in its ethical code. Such rules are in place to guide the actions of the members of a given profession. Most professions currently adhere to a general rule of confidentiality but allow exceptions in certain circumstances. For example, the American Psychiatric Association's code of conduct includes a rule that allows a psychiatrist to breach her client's confidence whenever that client poses a significant threat of harm to himself or an innocent third party.! One encounters similar exceptions to confidentiality in other professional codes of ethics. These exceptions seem to suggest that a client's 'right to privacy' sometimes conflicts with the basic rights of others, such as the rights to life and bodily integrity. However, I shall argue that this conflict does not seem to provide a sufficient reason to break a client's confidence.

I will begin by outlining one dilemma faced by professionals in regards to confidentiality, namely, that of choosing between maintaining a client's confidence or violating it in order to protect a third party at risk of harm. Of particular interest to me is the professional confronted by an "uncooperative" HIV-infected client - someone who presents a significant threat of harm to a third party, yet refuses to warn that person of the danger. The harm mentioned in this particular case, of course, is the transmission of HIV from the infected client to an unsuspecting third party. I will lay out this dilemma in concrete form in the second section.

Next, I will establish a justification for the importance of confidentiality in the professional setting. Although the duty of confidentiality is considered by most to be a crucial fixture in 
relationships between professionals and their clients, there is disagreement about the scope or strength of this duty. The California Supreme Court case Tarasoff v. University of California (1976) established case law requiring psychiatrists to break confidence whenever doing so would protect third parties at risk of harm from their clients. I will lay out the details of this landmark case later in the paper and will argue that the case may have been wrongly decided.

I shall also make a case for the assertion that HIV/AIDS raises several unique difficulties in terms of confidentiality and privacy. In addition, I will present some of the most common arguments for and against partner notification in cases of HIV/ AIDS. ${ }^{2}$ Although in this paper I am not arguing for or against a formalized program of partner notification, it might be helpful to look at arguments on both sides of the issue in order to bring to light concerns that often arise in considerations of notifying at-risk partners.

I will then take as my task to look at the issue of confidentiality from the perspectives of two very influential philosophical traditions: Kantianism and act utilitarianism. On my interpretation of Kantian moral theory, Kant would advocate an absolute rule of confidentiality - one that allows no exceptions whatsoever. The act utilitarian, on the other hand, would allow for exceptions to a general rule of confidentiality. Such exceptions would be generated by considerations of utility, meaning that whenever breaking a client's confidence would promote more good than maintaining it, then the client's confidence should be breached. In my view, the best position on confidentiality represents a compromise between these two approaches.

I will advocate a rule utilitarian approach to considerations of confidentiality in the professions. I take rule utilitarianism to be a compromise between act utilitarianism and Kantianism because it borrows important features from each theory and combines them into an attractive synthesis. Rule utilitarianism takes from Kant's theory the notion of impartiality. Kant, by emphasizing universalization as the test for formulating moral rules, attempts to eliminate instances in which people make exceptions of themselves. Maxims of action that fail the universalization test are taken to be moral prohibitions, and these prohibitions are absolute moral rules 
of the form 'never do such and such.' Similarly, rule utilitarian rules are absolute. But Kant does not give consequences as much consideration as he should. Rule utilitarianism remedies Kant's complete denial of consequentialism by basing its rules on their conformity to the principle of utility.

Although rule utilitarianism does allow exceptions to be built into moral rules, my particular view is that there can be no exceptions to an effective rule of confidentiality in the professions, where an effective rule is one that facilitates the proper functioning of the profession. In what will essentially turn out to be an argument by elimination, I will examine several possible rules of confidentiality with exceptions built into them, as well as the possibility of having no rule of confidentiality at all. After analyzing each of these rules and non-rules, and determining each to be inadequate for its intended purpose, I will ultimately argue that the only good rule of confidentiality in the professions is one that is exceptionless. Thus, a professional should never violate his client's confidence, even if doing so would prevent great harm to a third party at risk, as in the case of an uncooperative HIV-infected client and the person(s) he may intentionally harm.

\section{The Professional's Dilemma}

In order better to explain the professional's dilemma with regards to confidentiality, I shall outline a concrete example of a professional faced with a choice between maintaining his client's confidence or violating it in the interest of protecting a third party at risk of harm. Consider the following scenario:

A 32-year old man, married with two children, goes to his family practitioner to get an HIV test. His test results come back positive. As is customary when informing patients of test results in cases of HIV/ AIDS, the physician meets with the man to discuss the results and offer counseling. The physician informs his patient that he has tested positive for HIV and gives him information about the disease and its effects. He also advises the 
patient that he should inform his wife of his infected status and encourage her to get tested as soon as possible. Furthermore, the man should practice safe sex with his wife, if he does not do so already. However, during the course of the counseling session, the patient tells the physician that he likely contracted the virus during an encounter with a prostitute. The patient does not want to start wearing a condom during sex because it might make his wife suspicious; nor does he want to tell her that he is HIV positive because it will reveal his infidelity. Despite any advice the physician offers against this course of action, the patient insists on keeping his infected status a secret from his wife. The physician truly believes that his patient will intentionally put his unsuspecting wife in danger by exposing her unknowingly to the deadly virus. Should he warn his patient's wife of the potential danger?

On the one hand, the physician has a duty to respect the privacy rights of his patient. Therefore, he should not warn the man's wife of her husband's infected status. On the other hand, it seems inhumane to let an innocent third party come into harm's way when the harm could be prevented. Thus, the physician should warn the man's wife. This scenario provides just one example of the general dilemma facing any professional with a client who poses a risk of harm to an innocent third party.

Of course, the client can always waive his right to confidentiality, in which case it would be relatively noncontroversial for the physician, psychiatrist, health department official, and so on to warn the at-risk party because the client has given them permission to do so. In fact, this often happens in cases of people who test positive for HIV. Most of them either inform past and present sexual or needle-sharing partners of their infected status on their own or enlist the aid of public health officials in doing so. But these are not the interesting cases. The tough issue involves actions that stand in direct opposition to the wishes of the 
client, and the pertinent question is whether it is ever morally permissible for a professional to break her client's confidence. The case outlined above provides an example of the confidentiality dilemma in instances of partner notification in cases of HIV/AIDS. In section five, I will elaborate on the unique repercussions of breaches of confidentiality in HIV cases.

\section{In Defense of Confidentiality}

The importance of confidentiality in the professions has been defended from several viewpoints. Beauchamp and Childress lay out the argument from consequentialism in their discussion of confidentiality in Principles of Biomedical Ethics. ${ }^{3}$ From the consequentialist perspective, confidentiality facilitates the proper functioning of the beneficial role that a profession plays within society. Professions such as psychiatry, medicine and law exist because they serve a utilitarian social function. For example, psychiatric professionals often treat potentially dangerous patients who have psychiatric disorders, which may cause them to harm themselves or an innocent third party. It promotes overall wellbeing when psychiatrists are able successfully to treat a mentally ill client, thus increasing the happiness of that particular client, as well as preventing possible maleficent actions the patient might have performed if untreated.

Because a given profession promotes social utility - and I will continue to use psychiatry as my example for the sake of continuity - we want the professional to be successful in his mission. However, successful treatment depends on the completeness of the personal information the client communicates to the professional. For instance, if a psychiatric patient is not willing to disclose fully her feelings, then the psychiatrist likely will not be able to make an accurate diagnosis of the client's condition. Therefore, confidentiality must play a role in the relationship between professionals and their clients. Beauchamp and Childress point out that "Assurance of confidence is of paramount importance because it allows people to seek help without the stigma that would result from public knowledge: It encourages full disclosure essential for effective treatment, and it is necessary for the maintenance of trust." 4 
A client who is aware that what she communicates with her therapist will never be shared with a third party is more likely to disclose fully her feelings than the client who fears that her private information will be leaked to persons outside the professional-client relationship. Thus, confidentiality is justified from a consequentialist perspective insofar as it promotes social utility.

\section{The Tarasoff Precedent}

Although some form of confidentiality is generally considered to be important in maintaining the professional-client relationship, there is wide disagreement about the proper scope of confidentiality. That is, some people argue that the principle of confidentiality should govern all communications between a professional and his client, while others believe that certain information falls outside the purview of confidentiality.

A majority of the judges in the landmark California Supreme Court Case Tarasoff v. University of California (1976) took the latter view of the professional duty of confidentiality. The case in question involved two University of California students - Prosenjit Poddar and Tatiana Tarasoff. Prosenjit and Tatiana dated for a short time, but Tatiana quickly lost interest when she began to notice Prosenjit's possessive behavior patterns. Tatiana took a summer trip to Brazil to avoid her possessive suitor. Soon after Tatiana's departure, Prosenjit became very depressed, and he began seeing a psychiatrist at the university hospital in 1969.

During these sessions, Prosenjit confessed his intention to kill Tatiana when she returned to the country at the end of the summer. The psychiatrist treating Prosenjit, Dr. Lawrence Moore, notified campus police officers and requested that they detain Prosenjit for civil commitment. The police took Prosenjit into custody, but then released him after he promised not to harm Tatiana. The Director of Psychiatry at the hospital ordered that Prosenjit's file be destroyed and that no further attempt be made to have him committed. Prosenjit ended therapy and moved in with Tatiana's brother, very near Tatiana's apartment. When she returned to the country in October, Prosenjit went to her apartment to talk with her, and when Tatiana refused, Prosenjit stabbed her to death with a kitchen knife. 
Tatiana's parents brought suit against both the psychotherapist who had treated Prosenjit and the University of California for failing to warn Tatiana or her parents of the threat Prosenjit posed to their daughter. The now familiar duty to warn arose out of the ensuing trial in 1974. Confusion surrounding this first trial prompted many professional agencies to urge the court to rehear the case, and it did, in 1976. Justice Tobriner, in the majority opinion in Tarasoff $I I$, writes, "When a therapist determines, or pursuant to the standards of his profession should determine, that his patient presents a serious danger of violence to another, he incurs an obligation to use reasonable care to protect the intended victim against such danger."s This opinion established the obligation for professionals to warn third parties, or take whatever measures necessary to protect them from harm threatened by their clients."

However, not everyone agrees that the judges in the Tarasoff case made the right decision. The case law established in the trial places the public well-being ahead of the privacy rights of individual clients. But one might argue that there is value in maintaining secrecy about information that might cause harm to the client if it were revealed to third parties. A client's HIV-positive status certainly falls into this category.

\section{Special Considerations in HIVI AIDS Cases}

I chose the uncooperative HIV-infected individual as the example case for this paper because AIDS is an important contemporary issue, and because this particular case presents such a difficult dilemma in terms of confidentiality. There tends to be a division of concern between people in danger of contracting HIV and those people who already have the disease and are forced to deal with the controversy and social stigma that has surrounded HIV/AIDS from its very beginnings as an epidemic. Simply stated, the dilemma seems to present a choice between protecting the public health or protecting the privacy rights of particular individuals.

In June of 1981, the first cases of a strange immune system failure in the gay male community began to surface. ${ }^{7}$ Approximately one year later, in July of 1982, public health officials in the United States named this new disease AIDS. ${ }^{8}$ Because of its origins in the 
gay community, AIDS was commonly called "gay cancer," among other things, and infected persons were ridiculed and often blamed for their own suffering. However, by 1982, the disease had begun to appear in hemophiliacs as well, signaling that it was not just transmittable through intimate homosexual contact, but also through the blood supply. ${ }^{9}$ Seventeen years later, despite knowledge that HIV can be transmitted through both heterosexual and homosexual sex, as well as through needle sharing among intravenous drug users, HIV/ AIDS still often means enormous social stigmatization for those who are infected with the disease. Since the emergence of the disease, there have been massive efforts to educate the public about modes of HIV transmission and to combat discrimination against infected persons. Scientists are still searching for a cure for HIV/ AIDS.

Procedures for intervention in past sexually transmitted disease outbreaks have been the employment of mandatory names reporting of infectious persons, contact tracing of past sexual partners who may have been exposed, and even quarantine to protect the general population from the risk of infection. The concept of partner notification was introduced in 1937 by Surgeon General Thomas Parran for the control of syphilis. 10 Tracing and treating every known contact of a syphilitic patient could interrupt the chain of transmission. Beginning in the late 1950's, contact tracing has been successfully used in a number of STDs such as syphilis, endemic gonorrhea, chlamydia, hepatitis B and several other infections." Gerald Stine writes that "The strategy in HIV partner notification is the same as that used for the other STDs: to identify HIV-infected individuals, counsel them, and offer whatever treatment is available."12 This strategy emphasizes the prevention of HIVtransmission by informing uninfected persons that they are at risk, and urging those persons who have already contracted HIV to alter their high-risk behaviors in order to prevent further disease transmission. While this strategy for partner notification seems simple enough, not everyone agrees that HIV/AIDS is enough like other STDs that it should be treated in the same way.

Some proponents of partner notification argue that HIV/AIDS is similar to other STDs and should, therefore, be treated like other STDs. Tom Coburn cites the fact that traditionally enacted public 
health procedures have curtailed the spread of other STDs and argues that "partner notification is the only timely way to alert those in danger of infection."13 In opposition, though, Kenneth Mayer argues that HIV is not like other STDs. He says that "HIV's stigma forces many to live in fear of losing their jobs, homes, health insurance and families. It deters many from being tested, let alone treated." $14 \mathrm{He}$ argues that a national database of HIV-infected individuals and national tracing of their sexual contacts will simply steer more "at-risk" people away from medical intervention.15 Furthermore, past contact tracing has been performed within carefully targeted and resource-intensive STD control programs, a strategy useful for diseases with short incubation periods and wellknown, low-cost cures or treatments that are easily attainable. Mayer says that HIV does not fit this description, and that contact tracing for HIV would be costly and ineffective. ${ }^{16}$

As illustrated by Mayer's concerns, some people view HIV/ AIDS as a disease that gives rise to special considerations when drafting official policy. In the next section, I will lay out in more depth the arguments for and against a widespread program of partner notification in cases of HIV/AIDS. At least one of these arguments stems from considerations of the importance of confidentiality.

\section{Partmer Notification: For and Against}

There is a great deal of non-philosophical literature about the pros and cons of partner notification as a method of curtailing the spread of HIV/AIDS. The following list is typical of the arguments for and against partner notification found in articles in medical journals.

In "Partner Notification in the Control of Human Immunodeficiency Virus Infection,"17 J. B. Muth and his colleagues cite three major objections to contact tracing for HIV/AIDS. First, critics of contact tracing argue that it is inordinately expensive. Contacting every sex or needle-sharing partner of an HIV-positive individual requires a great deal of time, and paying employees to perform these searches is expensive. It is often very difficult to find a partner about whom the infected patient has little identifying information, or to trace people who have moved or changed names. 
Furthermore, it is expensive to administer AIDS testing and provide counseling to new contacts. Muth and his colleagues argue in opposition to this objection by noting that while the estimated cost of partner notification programs is expensive, it is not "staggering," and it is worth the cost if lives are saved in even a few cases. Furthermore, a significant amount of money could be saved on treatment costs if HIV transmission were prevented.

Second, critics of contact tracing argue that the procedure has negligible utility in the absence of effective medical intervention. This objection points to the fact that there is no existing cure for AIDS, only drugs with the potential to prolong an often very painful life. In light of the absence of a cure, many critics question the worth of notifying at-risk partners - prying into their personal lives and ripping them apart - when there is essentially nothing one can do to cure them if they test positive for HIV. Muth and his colleagues respond to this objection by arguing that although neither a vaccine nor a life-saving treatment is available for HIV/ AIDS, lifeprolonging compounds have been developed and others likely will be. Even if the only provision offered to newly notified parties is counseling designed to discourage high-risk behaviors that often lead to HIV transmission, its effects on society could be substantial. For example, a woman planning to conceive a child might alter her plans if she finds out she is HIV positive. Even if she is already pregnant, she might begin taking AZT, a drug that significantly reduces the risk of transmitting HIV between mother and child.

Finally, opponents of contact tracing argue that contact tracing leaves the door open to excessive potential for personal stigmatization and discrimination. ${ }^{18}$ Even if health department officials ensure absolute confidentiality when notifying at-risk partners, this assurance is often not enough to keep notified parties from deducing who it is that might have given them the virus. The person notified may have had intimate sexual contact with only one person in her lifetime, and thus, it would be safe for her to assume that her partner in that particular instance was the person who passed the disease on to her. Furthermore, the notified party might become angry enough to tell other people about the HIVpositive status of her partner. Therefore, complete confidence could not be assured within a program of contact tracing. Muth et al. 
respond by asserting their belief that adequate legislative protection for public health records and data is achievable. They cite the fact that health departments in the United States have a long and wellestablished track record of protecting patient confidentiality. ${ }^{19}$

Stine adds two more objections to partner notification to this list. First, he cites the argument that there is not much evidence that those who are informed of their infection will change the highrisk behaviors that led to their infection in the first place. Stine also cites the fact that homosexuality is a crime in twenty-four states, and HIV-infected homosexuals fear prosecution for themselves and their sexual partner(s) if they acknowledge same-sex contacts. ${ }^{20}$

In addition to these arguments against contact tracing, Franklyn Judson writes that people who oppose partner notification often cite the number of contacts missed as a good justification for abandoning the effort.21 But although partner notification may seem ineffective if the individual case is the only unit of analysis, Muth et al. argue that "viewed in the aggregate ...the case finding outcomes are likely to be more productive than they appear individually."22 They also claim that there will be a lot of overlap among names mentioned because groups with the highest risk behaviors are small relative to the overall population. In addition, "over time, the proportion of located contacts who are newly identified as positive should diminish, testifying to diminished HIV transmission."23

Further advantages to partner notification are that it targets persons who are most likely to have been exposed to the infection. It also counterbalances the tendency of persons with high-risk profiles to be least inclined to seek counseling and testing services: "By personalizing the epidemic, partner notification not only discourages denial but also helps identify persons who otherwise may not perceive themselves to be at risk, especially exposed women in their child-bearing years." 24 Finally, proponents of partner notification argue that although partner notification is labor intensive, it is operationally simple. Almost all aspects of caseinterviewing, case-finding, testing and condom dispensing can be done in the field.

Stephen Josephs questions opposition to partner notification: 
How can one justify, on clinical, public health or humanitarian grounds, not notifying that surviving partner, who might be the source of the infection in the deceased, or the recipient of infection? Arguments against this procedure border on the absurd; one has to start with the premise that increased medical knowledge is more dangerous than helpful to the individual, and that the rights of the uninfected count for nothing against the rights of the infected. ${ }^{25}$

Josephs argues that vigorous contact tracing, under conditions of strict confidentiality, is the most important step in reducing further progression of the HIV virus, and protecting those who, though unsuspecting, are at greatest risk of infection or in greatest need of early medical intervention. 26

In light of all the advantages cited by proponents, it may seem strange that opposition to partner notification in HIV/ AIDS cases still exists. One of the biggest obstacles to achieving widespread agreement with regard to partner notification is a concern with confidentiality and privacy. Gunderson, Mayo and Rhame write, "It is not an exaggeration to say that a person who is HIV infected may risk social death long before he or she faces physical death. HIV-infected persons have powerful prudential reasons for not wanting knowledge of their infected status to fall into the wrong hands." 27 Gay leaders in the late eighties expressed similar fears about discrimination that might result from enacting a partner notification program. A proposal in San Francisco that the health department provide contact tracing services to bisexual men whose female partners were at high risk of being exposed to the disease "was denounced as Orwellian because of the prospect of creating lists of bisexual men and their partners." 28 A similar proposal by the Minnesota Health Department in 1986 prompted one opponent of contact tracing to cite the fact that " the road to the gas chamber began with lists in Weimar Germany."'29 Muth's general citation of the reputation of public health agencies in maintaining confidentiality seems like an unconvincing response to these very serious concerns. 
Although I do not want to deal in this paper with the ethics of a formalized partner notification program, understanding the concerns that trouble opponents of such programs illuminates some unique problems one should consider when deciding whether it is ever morally permissible to warn, against a client's wishes, persons at risk of contracting HIV from that client. The consequences of widespread knowledge of a person's HIV-positive status can lead to horrific social, financial and personal conflicts for the infected individual. Recognizing this fact makes it more difficult to make hasty decisions in favor of warning at-risk parties in order to prevent the spread of HIV.

\section{Kantian Ethics}

Before I attempt to give the Kantian response to the question of whether breaches of confidence are ever morally permissible, it might be helpful to introduce the main ideas of Kant's moral theory. Immanuel Kant envisioned morality as a system of categorical imperatives, where categorical imperatives are commands of pure practical reason, which command categorically, meaning that they cannot be overridden by human desires. It is crucial to Kant's theory to distinguish categorical from hypothetical imperatives. The distinction in question is one between moral and non-moral 'oughts.' That is, hypothetical imperatives come into being as a result of some actual or possible desire and introduce a relationship of practical necessity. For example, 'if Ryan wants to go to graduate school, then Ryan ought to take the GRE.' This imperative gives the required action for fulfilling a possible desire. However, the 'ought' in this command is not a moral ought, but simply an instrumental ought. Thus, if Ryan does not wish to go to graduate school, then Ryan need not take the GRE. The obligation expressed in a hypothetical imperative simply dissolves when the desire is removed.

In sharp contrast, categorical imperatives are not desiredependent. The obligations embodied in categorical imperatives are moral obligations that prescribe duties. Kant holds that actions performed from duty are morally right, not because of the consequences generated by their performance, but instead, because 
of the very fact that they are performed from duty. He writes that categorical imperatives are "not concerned with the matter of the action and its intended result, but rather with the form of the action and the principle from which it follows; what is essentially good in the action consists in the mental disposition, let the consequences be what they may."30 We will soon see that, with respect to consequences, Kant means what he says.

Kant claims that all of our moral obligations can be derived from a single moral principle, which he calls the Categorical Imperative. In the Groundwork of the Metaphysics of Morals, he states the Categorical Imperative in the following terms: "Act only according to that maxim whereby you can at the same time will that it should become a universal law."31 Among other duties, Kant argues that perfect duties to others can be derived from this principle, and he offers the rule against false promising as an example of how to derive such a duty. Kant imagines a situation in which a man in need of money borrows it from a friend, even though he knows he cannot repay it. He knows he must promise to repay the money within a certain period of time in order to get the loan, but he also knows that such a promise would be a false one since he could not possibly pay the money back. The man asks himself whether this action would be contrary to duty.

In order to make this determination, he must first determine the maxim of his action, which can be expressed in the following terms: "When I believe myself to be in need of money, I will borrow money and promise to pay it back, although I know that I can never do so." 32 Next, the man must universalize this maxim to see how things would stand if it were a universal law of nature. Fred Feldman, in "Kantian Ethics," explains Kant's procedure for universalization by distinguishing between the "generalized form" of a maxim and what I will call the maxim's individual form. ${ }^{33}$ The maxim of false promising, stated above, fits Feldman's form of an individual maxim: "Whenever I am __, I shall __."34 In order to universalize this maxim, we must expand it to its generalized form: "Whenever anyone is , she will

Kant's universalized form of the maxim for false promising fits well in Feldman's model: "anyone believing himself to be in difficulty could promise whatever he pleases with the intention of 
not keeping it." 35 Although this proposition might be compatible with one's own future welfare, says Kant, it does not stand up under universalization because it would be "self-contradictory." 36 There has been some confusion about what Kant means when he says that a maxim is self-contradictory. One popular interpretation suggests that, for Kant, a maxim is contradictory when universalizing it would destroy the institution invoked by the maxim. For instance, in his example of promise keeping, a maxim that allows false promising would be self-contradictory because it would somehow destroy the institution of promising itself. Were it really the case that willing a maxim of false promising to be a universal law would destroy the institution of promising altogether, then this version of 'contradiction' might be plausible because in a world in which no promises existed, it would be logically impossible to will a false promise as the means of extricating oneself from difficulty. However, willing a maxim of false promising to be a universal law does not create a world void of promises. If everyone made false promises, then eventually, no one would believe anyone else's promises. However, an atmosphere of distrust does not entail the complete obliteration of promises. Promises can still be spoken of, even in a world in which no promise is ever believed. That is, promises can still exist - promises can even be issued - in a world that includes a universal law of false promising. While there are a few places in the Groundwork where one might construe Kant to be endorsing the view that universalizing a maxim of false promising destroys the institution of promising itself, I think it is more accurate, in view of the entire work, to attribute to Kant a different interpretation of 'self-contradictory.' 37

A more comprehensive interpretation of Kant's moral theory yields the conclusion that propositions are contradictory insofar as they violate the following principle, which Kant takes to be an analytic truth: "Whoever wills the end, wills ... also the means that are indispensably necessary to his actions and that lie in his power." 38 Thus, Kant holds that a rational person who wills an end wills also the means necessary to achieve that end. Suppose that a rational person adopts the following maxim: "In order to get money I will make a false promise." If false promising were the universal means of achieving the end of acquiring money, though, then no 
one would believe promises made in situations where the promiser needed cash. Therefore, willing a maxim of false promising to be a universal law would remove the means by which the promiser could get the money she needs. Hence, by willing the maxim to be a universal law, the promiser simultaneously wills both the end of acquiring money and the elimination of the means of acquiring this money. That is, she simultaneously wills both to get the money and not to get the money. And this is just to say that she wills both $\mathrm{p}$ and not-p simultaneously. Thus, by willing that the maxim become a universal law, she wills a logical contradiction. Christine Korsgaard, in "Kant's Formula of Universal Law," 3 " endorses this interpretation of 'contradiction' in Kant's writings. Regarding a maxim of false promising, Korsgaard writes:

In the world of the universalized maxim, the hypothetical imperative from which the false promiser constructs his maxim is no longer true. It was 'if you want some ready cash, you ought to make a false promise.' But at the same time that he employs this hypothetical imperative in constructing his maxim, he wills its falsification, by willing a state of affairs (the world of the universalized maxim) in which it will be false. ${ }^{+1}$

Thus, when Kant claims that the maxim for false promising could not hold as a universal law of nature, he means that if all people took as their maxim, "whenever I am in difficulty I will extricate myself from that difficulty by means of a false promise," then any time someone in a difficulty made a promise, no one would believe the promise because everyone would be aware of the maxim that allowed false promises. But if no one believed promises made in these situations, then no one would ever provide the means needed to extricate the promiser from difficulty. Thus, by willing the maxim of false promising to be a universal law, one simultaneously wills to eliminate the means of achieving the intended end of the action. In the case of borrowing money, willing the maxim of false promising to be a universal law would result in public knowledge 
of the falsity of the borrower's promise to repay the loan; and therefore, no one would lend the man money. By universalizing his maxim, he wills the defeat of the end of his action: acquiring cash.

\section{Kantian Approach to Confidentiality}

In the previous section, I outlined Kant's derivation from the Categorical Imperative of a perfect duty against false promising. If breaking a client's confidence is equivalent to breaking a promise made to that client, then Kant would have to be opposed to performing such an action. Thus, it might be helpful for our purposes to conceptualize a breach of confidence as a broken promise. If breaking promises is always prohibited, and breaching client confidence is an instance of breaking a promise (and I will argue that it is), then we can conclude that Kant would advocate an absolute rule of confidentiality.

Consider the following promise: "I promise to keep all client information in the strictest confidence, unless by breaking my client's confidence, I can prevent harm to a third party." In this case, the scope of the promise of confidentiality is limited by an exception, or a condition. This promise makes confidentiality conditional on the type of information shared by the client. If the client communicates intent to harm an innocent third party, then the promise is void because this type of information is not covered by the promise. In this example, then, warning third parties at risk of harm from your client is not a breach of confidence, nor a broken promise.

However, a professional rule that entails such a promise is a foolish rule. If a client knows that information about intent to harm third parties is not covered by the promise of confidentiality, then the client will not divulge information of this nature. Thus, the professional will be in no position to protect a third party at risk of harm because he will not be aware that any danger exists. Hence, a promise of confidentiality with built-in exceptions defeats the purpose of having the exceptions to begin with, which in this particular case is to prevent harm to third parties at risk. 
Therefore, the only promise of confidentiality Kant could allow is one that is absolute, such as, "I promise to keep absolutely all client information in the strictest confidence." But if this is the promise made to clients, then all breaches of confidence are cases of breaking promises. And since Kant believes that false promising is morally prohibited, then breaking confidence under his view is never morally permissible. Thus, in regards to the professional's dilemma in the case of the uncooperative HIV/AIDS client, Kant would argue that the professional is obligated to remain silent, even though his motivation for speaking out is a concern for preventing the death of an innocent third party.

There is one point, in Lectures on Ethics, where Kant diverges from his otherwise absolutist stance against lying or breaking promises. He writes, "The forcing of a statement from me under conditions which convince me that improper use would be made of it is the only case in which I can be justified in telling a white lie." 4 I Kant argues, in this segment, that a lie can justifiably be used as a "weapon of defense." 42 However, he goes on to write that "a lie is a lie, and is in itself intrinsically base whether it be told with good or bad intent ... There are no lies which may not be the source of evil." 43 Furthermore, the rest of Kant's ethical writings indicate his belief in a moral prohibition against lying or breaking promises. Regardless of where Kant came down in the end, an argument against ever telling a lie or breaking a promise can be made using Kant's Categorical Imperative.

But many intelligent people think such an argument is too stringent. For example, the judges in the Tarasoff case ruled that the prevention of harm to a third party at risk is, in fact, a very compelling reason to break a client's confidence. Be that as it may, though, Kant has shown himself to be serious about the exceptionless nature of our moral obligations. For instance, in his essay, "On a Supposed Right to Lie from Altruistic Motives," Kant advocates the view that one is morally obliged to be truthful with a murderer who comes to one's door looking for a friend one is hiding in the closet. Even in this case, when lying might save another's life, one is obligated to be honest with the murderer. Kant writes, "it [truthfulness] ... is an unconditional duty which holds in all circumstances." 44 Although lying to a murderer about the 
whereabouts of a friend may seem, intuitively, like the right thing to do, Kant might have us imagine a world in which something like the following maxim of action were a universal law: in order to prevent great harm to others, I will lie to protect them. Kant seems to think that lying to the murderer at the door would generate a logical contradiction. That is, if we imagine the above maxim as both universal and public, then everyone would know that whenever we were trying to prevent harm to a third party, we would lie to protect them. Thus, no one would believe us when we claimed to be ignorant of the potential victim's whereabouts.

Therefore, by willing the maxim as a universal law, we simultaneously will the elimination of the means of achieving our end of protecting the third party from harm. In order for lies to work, one must be deceived by them. But if the murderer does not believe the lie because of the maxim that allows lying to protect people from harm, then the lie will not deceive him. Thus, the murderer might storm into your home and find his victim anyway, despite any information you provide him with. The lie in this case will be no more efficacious than the false promise in Kant's example of the man in need of money who borrows it and promises to repay it, even though he knows he will never be able to do so.

James Rachels objects to Kant's view that it is always immoral to lie, even when doing so will save the life of a third party. $\mathrm{He}$ argues for what is a common position against Kant. That is, he claims that the maxim of our action could be rephrased so that it could be universalized without contradiction. Rachels agrees that Kant's formulation of the maxim, "in order to prevent great harm to others, I will lie to protect them," does not pass the universalization test. However, he argues that this maxim for lying could be rewritten to meet the criterion for universalization in the following way: "'It is permissible to lie when doing so would save someone's life." 45 Rachels claims that one could will that this maxim become a universal law without its being self-defeating. Problematically, though, he does not provide any proof for this assertion. In fact, if one works out the derivation, one realizes that the maxim does not pass the universalization test. Rather, it is selfdefeating. For the end of the proposed action is to save another's life. However, if everyone knew that people lied when they were 
in the position to save someone's life, then no one would believe such lies. Thus, no one's life could be saved on this approach, and therefore, it does not follow from Rachels' lying maxim that Kant's overall argument against lying is invalid. Rachels' analysis has no affect on the truth of Kant's claim that all lying is morally prohibited because, in order to prove his claim, Kant needs only one derivation from the Categorical Imperative that demonstrates the impossibility of willing as a universal law a maxim of lying to prevent harm. As illustrated earlier, Kant provides this proof.

Rachels anticipates this response to his objection and attempts to counter it by claiming that Kant's vision of the murderer's behavior is unrealistic. Kant argues that lying would not protect anyone from harm because murderers would not believe us if lying were a universal law. But Rachels says, "they would believe us if they thought we did not know what they were up to; and if they thought we did know what they were up to, they would not bother to ask us in the first place. This is no different from the situation that exists now, in the real world: murderers know that people will not willingly help them." 46 Korsgaard puts forth a similar argument in her essay, "The Right to Lie." 47 She challenges the idea that a murderer would come to your door asking about the location of a friend of yours whom he would like to kill. She says that "A murderer who expects to conduct his business by asking questions must suppose that you do not know who he is and what he has in mind." 48 She claims that a universal practice of lying could be permissible under these circumstances since your lie would be efficacious because the murderer would assume that you did not know you were addressing a murderer. That is, the murderer does not assume that you will lie because he does not believe you are aware of your circumstances.

However, Korsgaard's (and thus Rachels') criticism of Kant seems to be flawed for the following reason: she assumes that the person who answers the door is a utilitarian. She says the murderer must assume that the person who answers the door does not know who he is and what he has in mind. But why does Korsgaard think the murderer must assume this? Because she believes that if the person who answers the door knows the person standing there is a murderer - and thus realizes the deadly consequences of telling 
the truth about the location of her friend - then the person who answers the door will not help the murderer. But again, this line of reasoning assumes that the person answering the door is a consequentialist. So how is this view available to Kant, who is a non-consequentialist? Why not assume that Kant answers the door? If this were the case, then it would not matter what the murderer assumed about Kant's knowledge of his purposes. Even if Kant realized that he was being confronted by a murderer, he would still reveal the whereabouts of the potential victim because he holds that lying is impermissible in all circumstances.

But let us assume that Rachels' and Korsgaard's observations concerning human behavior are correct. Their comments still are not problematic for Kantianism. Suppose one knew that she was dealing with a murderer at the door, but the murderer did not believe that she knew. In this case, lying might be effective in warding off the murderer. But why should we imagine this particular epistemic situation? Both Rachels and Korsgaard admit that murderers assume we do not know what they are up to when they ask us questions about intended victims. In fact, it is quite likely that we would not know we were being confronted by a murderer in such a situation. But if we were unaware that we were being confronted by a murderer, then the maxim of our action could not be "lie to prevent harm to a third party" because we would not know we were in a position to prevent such harm. Thus, we would not know it was a situation in which we should lie to protect our friend, and without being aware that we were in a situation described by the lying maxim, we might reveal the location of our friend and thereby jeopardize her life.

Besides, we can imagine other cases in which Kant's argument against lying in order to prevent great harm to others clearly remains sound. For instance, suppose it is 1940 and you are living in Nazi Germany. SS officers are quite well known and very easy to identify. It is also known that these soldiers are searching for Jews, and when they find them, they take them to camps where they are tortured and, most often, murdered. Suppose you are hiding Jews in your attic. If an SS officer came to your door and asked if you were hiding Jews, you would know that the soldier intended great harm to the Jews. Yet, could you, in order to prevent harm, lie to 
the soldier about your knowledge of the Jews' whereabouts? Kant would argue that you could not lie, even in this extreme situation, because the maxim of lying fails the universalization test. If this maxim were both universal and public, then the soldier would not believe your lie, but would instead search every single house for hidden Jews. But if he searched every house, then no one would be protected from harm. Therefore, the universalization of the maxim generates a contradiction inasmuch as it eliminates the means to achieving the intended end of the action. Rachels' and Korsgaard's respective claims that murderers assume we do not know what they are up to does not apply in this case because SS officers are identifiable by their uniforms as known murderers. Thus, they would not assume that you did not know what they were up to when they came to your door.

Therefore, it seems evident that Kant is serious when he talks about the absolute nature of certain of our moral duties, as shown in his prohibitions against lying and breaking promises. It follows that he would be equally serious about a duty against breaking confidentiality. However, I think it is important to understand the duty of confidentiality in the professions as more than just a duty prescribed by moral law, but as a duty that corresponds to moral law while simultaneously promoting optimific consequences within the framework of society. That is, the duty of confidentiality, like all duties that can be generated from Kant's Categorical Imperative, should eliminate partiality. No one person should be able to make an exception of himself. In addition, though, moral duties should, at least in some way, promote the interests or well-being of the members of the society they govern. The promotion of well-being through the consequences of an action, though, is a utilitarian, not a Kantian concern.

\section{Act v. Rule Utilitarian Ethics}

In sharp contrast to Kant's deontological absolutism is the consequentialist moral philosophy known as utilitarianism. Consequentialism determines the rightness or wrongness of an action based solely on the consequences generated by its performance. Under the view of John Stuart Mill, perhaps the most 
well known utilitarian, those actions whose consequences produce the greatest amount of happiness overall are taken to be morally right actions. This feature of Mill's theory is expressed in his "greatest happiness principle," which maintains that "actions are right in proportion as they tend to promote happiness; wrong as they tend to produce the reverse of happiness. By happiness is intended pleasure and the absence of pain; by unhappiness, pain and the privation of pleasure." 49 This principle is supposed to serve as a guide for making decisions about actions. While it is unclear whether Mill is an act or a rule utilitarian (or both), I will begin with a discussion of act utilitarianism.

Some have found act utilitarianism to be a more acceptable moral doctrine than Kantian ethics because they believe that, in many cases, it conforms more readily to standard morality. These people think it is a mistake to overlook the consequences of an action when making determinations about the action's moral worth. Furthermore, many find Kant's rigid rejection of exceptions to moral rules contrary to what they consider the moral course of action. Act utilitarianism, though, by taking into account everyone's interests equally and allowing for a case by case evaluation of the moral worth of actions, seems to avoid some of these criticisms. Act utilitarianism evaluates individual actions based on their conformity to the principle of utility. Later, I will discuss another version of utilitarianism that utilizes the principle of utility to develop moral rules, which then become the moral standard by which individual acts are measured.

Under act utilitarianism, no one person's well-being is more important than that of another person. Society is viewed as a whole, and the aggregate well-being is what counts. Thus, the act utilitarian professional considering whether to breach her client's confidence would have to give equal consideration both to the well-being of her client and to that of the third party at risk of harm. But these considerations do not rule out breaking the promise of confidentiality. In fact, if breaking the promise would promote more well-being overall, then the professional is obligated to do so.

According to the act utilitarian, in the case of the man with a confirmed HIV diagnosis who refuses to inform his wife of his infected status, the professional must weigh the happiness of his 
client against the happiness of the other affected parties. The patient himself has already communicated that he does not wish for his wife to know about his infected status because it will reveal his infidelity and probably end his marriage. Thus, the client's happiness would be reduced if the physician broke his confidence. Not only would he be angry with the physician for breaching the doctorclient privilege, but also he would be devastated if his wife left him, taking their children with her. On the other hand, he might be equally devastated if his wife contracted the HIV virus as a result of his careless behavior. For that matter, his wife would be obviously worse off as well. She likely would feel resentment toward her husband and the physician because neither warned her of the impending danger. Furthermore, due to the chronic nature of AIDS, the couple's children would experience a great deal of unhappiness as a result of the premature deaths of their parents in the future. It seems clear that the most happiness would be produced in this particular situation if the physician warned the man's wife of the risk of harm she was incurring.

This kind of deliberation at first seems relatively clear cut. However, a problem arises with utilizing act utilitarian theory to make deliberations about confidentiality in the professional setting. If the decision to maintain or break confidentiality is relative to each particular case, then the professional setting has the potential to become a breeding ground for individual professionals to make unfair and inconsistent judgments about which actions promote the greatest good for the greatest number of people. If we leave these important decisions up to the discretion of individual professionals, there may be abuses resulting in unfair breaches of confidence. For example, a psychiatrist who fears that his own child will be killed by one of his patient's may feel he is justified in breaking his client's confidence by reporting the perceived threat to the authorities. After all, he does not wish to be responsible for the preventable death of his own child. However, the same psychiatrist might be less apt to break his client's confidence to warn a third party the psychiatrist does not know personally but who is in the same amount of danger as his daughter is in the first example. If the goal is to promote the greatest good for the greatest number of people, and warning his daughter accomplishes this goal, 
then warning a stranger presumably accomplishes the same goal. However, the personal nature of the threat to his daughter and the impersonal nature of the threat to a third party might prompt the individual psychiatrist to draw different conclusions about the permissibility of breaking his client's confidence in each situation. Therefore, the act utilitarian approach to confidentiality in the professions is inadequate because it leaves too much room for arbitrary decisions.

This last consideration has led our discussion into a new realm of utilitarianism. Traditionally, utilitarianism has involved evaluating actions on a case-by-case basis and determining which actions promote the greatest good for the greatest number of people in terms of the consequences of particular actions. This form of utilitarianism has been called act, or direct utilitarianism, and it can be contrasted with rule, or indirect utilitarianism. Both forms take as their ultimate end the maximization of human happiness, but each achieves that end in a different way. I have already described the methods of the act utilitarian. The rule utilitarian, in contrast, does not evaluate individual acts in terms of the overall utility of their consequences. Instead, she develops a set of rules, compliance with which maximizes utility, where the rules in question would have to be something other than 'act so as to promote the greatest good for the greatest number of people.' The choices to perform individual acts are then determined on the basis of whether they adhere to these moral rules.

If the professional setting is governed by ethical codes, then we must discuss utilitarian considerations in this setting in terms of rules. In a professional setting, the actions of the members should be guided by a general code of conduct agreed upon within the association in order to avoid the problems of inconsistency and unfairness outlined in the above discussion of act utilitarianism. Professionals faced with a tough ethical choice should consult the professional rules of conduct to aid them in making their decision. Thus, there must be some kind of uniformity across the board in terms of ethical policy, and these guidelines must be publicly available for purposes of informed consent. That is, a client who seeks the services of a professional must be informed of any policies that might affect the professional-client relationship. This kind of 
talk falls under the rubric of informed consent, which ensures that before one compromises oneself in any way, one is fully aware of all one's options and the resulting consequences of each of those options.

Although the professional setting seems to be governed best by rules, this is not to say that the rules will not have exceptions. In fact, it is common practice to build exceptions into the rules themselves. For example, we might imagine that the physician described above reaches the conclusion that he should inform the wife of the uncooperative AIDS patient through a process of reasoning that begins with a policy requiring physicians to maintain patient confidentiality, except in situations where the patient poses a significant threat of harm to an identifiable third party. As long as the exception is built into the rule ahead of time, then our application of the rule utilitarian approach in the case of confidentiality does not make it susceptible to the objection raised by David Lyons that rule and act utilitarianism are extensionally equivalent. This is a common objection raised against rule utilitarianism, and I will argue against this objection in section twelve when I lay out my own rule utilitarian argument in favor of an absolute rule of confidentiality.

We should return to the rule formulation stated above, though, which allows a professional to breach confidence in cases where a third party stands to be harmed by his client. If this rule were the policy of a professional organization, then the policy would need to be made clear to the public. Presumably, though, if the HIVpositive man described above knew about the policy that allowed physicians to break confidence in cases where a patient presents a significant threat of harm to a third party, then the man would not disclose his intention to keep his HIV-positive status a secret from his wife while continuing to practice unprotected sex with her. Instead, he would ensure the physician that he would inform his wife of the danger, and then he would leave the doctor's office and do exactly the opposite. Thus, under this policy, the physician would have absolutely no power to prevent harm to a third party at risk because the nature of the policy would drastically reduce the rate of patient disclosure of intention. And since the policy would fail 
to accomplish the results it was created to achieve, the policy would be unnecessary and might even cause more harm than good.

\section{Candidates for Professional Rule of Confidentiality}

In order to discover which rule would promote the best overall consequences, it might be helpful to formulate several experimental rules and then test them for efficacy. Although we will not be able to contemplate an exhaustive list, by covering rules from each of several categories we might be able to arrive at the best possible rule for confidentiality in light of the inadequacies of the other candidates.

Our first test case might be the rule formulation already considered above: a professional should always maintain her client's confidentiality, except in cases where the client poses a significant threat of harm to an identifiable third party. I have included the qualifying term "significant" to eliminate cases in which the harm is so minimal that warning would just upset a lot of people unnecessarily. The term "identifiable" is used in recognition of the fact that the professional has no recourse for preventing harm when she does not even know toward whom the harm is aimed.

Of course, I've already demonstrated how ineffective, and perhaps harmful, this policy might be. A rule that requires professionals to warn third parties at risk of harm at the hands of their clients would have to be made known to all clients under the professional's care or advisement due to considerations of informed consent. However, if this were the case, then clients whose intentions were to inflict harm on third parties simply would not disclose this incriminating information to their psychiatrists, doctors, and so on. Therefore, the point of instating the rule to begin with would be sorely missed in practice. Without the relevant information, professionals would not be in a position to help anyone at risk of harm.

Another option might be to have one rule for professionals and another for patients. That is, a professional association might advertise an absolute rule of confidentiality as the overall professional policy, but violate confidentiality when they deemed it appropriate. Under this approach, the public would believe that 
the professional policy of a certain organization was to ensure absolute client confidentiality, and therefore, the problem of inadequate disclosure would potentially be solved. Clients would be more likely to disclose the information necessary for the professional to treat their illnesses or mental disorders, or build a proper legal defense, but professionals would reserve the right to break confidence whenever they felt that doing so would promote the greatest good for the greatest number of people.

However, this approach seems obviously unethical. Failing to inform a client of a "secret" confidentiality policy that directly affects him violates the client's right of informed consent, and thereby fails to respect the client as an autonomous agent who has the capacity to judge for himself the pros and cons of various courses of action. A client who is unaware that the psychotherapist she is seeing operates under a secret professional code that allows her to disclose information of such and such a type might assume that all information shared within the confines of the professional setting will be held in the strictest confidence. Indeed, such an assumption is often considered to be an implicit feature of the professionalclient relationship. Breaking this implicit relationship constitutes a deliberate deception on the part of the professional to all clients, and deception has no place in the professional setting. Without a relationship of trust between professionals and their clients, professions fail to do the work they were created to do. Thus, the double rule model is inadequate.

Another alternative might be for a professional association to adopt a strong presumption in favor of confidentiality, but have no rule that addresses confidentiality directly. The public would be aware that this was the policy, and thus, there would be no difficulties with informed consent. However, it seems to me that the abandonment approach gets us no further than the act utilitarian approach. Without guidelines for making decisions, there would likely be inconsistency among professionals in the same field. The chances of a client's confidence being breached by a professional the client trusts might depend more on which professional the client chooses to go to rather than what type of information the client discloses. By having what one might call a 'non'-policy regarding confidentiality in the professions, we lose an important element of 
objectivity that seems necessary to ensure consistency and fairness when making decisions about breaching client confidentiality.

Furthermore, a rule that lacks specificity might impede disclosure even moreso than a rule that has only a few specific exceptions. That is, a client likely would refrain from communicating information if he knew' the professional would divulge information that fell under the specific exceptions to a rule of confidentiality. Certainly, this client would refrain from communicating if he thought the professional might divulge. In fact, it is likely that there would be even more instances of restrained communication in the latter, non-specific case.

As I have argued before, though, specifying the exceptions to a rule of confidentiality does not solve the problem of inadequate disclosure. If the client does not want anyone to know, he simply will not disclose information that falls under the exception clause. This can be extremely harmful, especially in cases where the exception deals with information about intent to harm third parties.

Exceptions to professional rules of confidentiality can result in negative events, not only for third parties affected by a dangerous client, but also for the client himself. Often the client is swayed from communicating to a professional the very thing with which the client needs the most help. In the case of a client who intends to commit future crimes, this intention needs to be addressed in order to help the client or a third party. For example, a client who, on a routine visit to his psychotherapist, confesses an urge to kill his exwife, needs to be treated. It is highly possible that after discussing his frustrations with his therapist and obtaining advice on how to deal with his stress, the man's urge will subside. Then, the psychiatrist will have done his job by successfully treating his client and simultaneously preventing a potential harm to a third party at risk. Yet, the therapist would not be able to accomplish this without full disclosure from his client. And since exceptions to rules of confidentiality impede full disclosure, they undermine the goals of a profession, which itself promotes social utility. 


\section{An Absolute Rule of Confidentiality}

I would argue, then, that any rule of confidentiality with exceptions built into it is self-defeating. That is, whatever end is intended to be achieved by including a given exception is always defeated because public knowledge of the exception eliminates client disclosure. In contrast, though, rules that fail to spell out specific circumstances under which it is permissible to break client confidentiality leave too much room for inconsistency and unfairness. In light of my negative analysis of both rules with exceptions and non-rules, I must conclude that the best candidate for a rule of confidentiality is one that includes no exceptions, but is, instead, an absolute rule. The only way for professions to function at the level at which they are designed to function is for all professions to adopt absolute rules of confidentiality. My argument, rule utilitarian in nature, looks like this:

1) Professions serve a desirable social function.

2) If professions are to fulfill this function, then clients must feel comfortable disclosing personal information.

3) In order for clients to feel comfortable disclosing personal information, absolute confidentiality must be ensured.

4) Therefore, absolute confidentiality must be ensured.

5) Therefore, breaches of confidence are never morally permissible.

This is a valid argument: if all the premises are true, then the conclusion must also be true. I have argued for all of these premises at other points in this paper, and therefore, I will not defend them here.

I will, however, address David Lyons' objection to rule utilitarianism mentioned earlier. Lyons contends that "a mere appeal to rules does not necessarily yield non-equivalence with simple [act] utilitarianism."'50 In effect, what Lyons argues is that rule utilitarianism cannot be distinct from act utilitarianism because he 
takes it that the only truly utilitarian rule is just the principle of utility: "act so as to promote the greatest good for the greatest number of people." If we choose any other rule, then there would almost assuredly be cases in which abiding by the rule would not produce optimific results, and allowing for cases that fail to produce optimific results is anti-utilitarian. But the rule stated above is just the equivalent of act utilitarianism. Thus, rule utilitarianism always collapses into act utilitarianism.

My intention is not to argue that Lyons' objection holds no water against other rule utilitarian arguments. However, I do want to contend that my argument regarding confidentiality is not susceptible to his criticism. Maintaining absolute client confidentiality in the professional setting always produces optimific consequences for society as a whole because without the assurance of confidence, clients would not willingly disclose information concerning maleficent intentions. But this is exactly the information that the professional needs to know in order to treat the client, and thereby prevent harmful consequences to third parties at risk. The assertion that there would be some instances in the professional setting in which having a rule that allowed breaking confidentiality would produce more good than abiding by an absolute rule is simply false. Therefore, my rule utilitarian argument for an absolute rule of confidentiality is not subject to Lyons' objection that rule utilitarianism always reduces to act utilitarianism.

\section{Conclusion}

Human beings live together in societies and should, therefore, consider the well-being of those who share their society. This cannot exclude considerations of how actions will affect other people. Because professions such as psychiatry, medicine and law tend to benefit society as a whole, we should make sure professionals are able to fulfill their utilitarian roles to the fullest. This involves having professional policies that enable professionals to provide the best aid possible to their clients. An absolute rule of confidentiality is one way to ensure that clients, and in turn society, reap the maximum benefit from these institutions. 
Some might want to say that my conclusion is implausible because of the case law established in the Tarasoff case, which prescribes not only a duty to warn, but an even broader duty for professionals to take whatever measures necessary to protect third parties at risk of harm from their clients. An absolute rule of confidentiality will often conflict with the law, and if it is always immoral to break the law, then the absolute rule must be immoral.

My response to this objection, however, is that the Tarasoff case was wrongly decided. Had the judges in this case made the correct considerations instead of appealing to their humanitarian intuitions, they would have concluded that absolute confidentiality is the only way to ensure the proper functioning of professions that promote well-being within society. Our laws do not entail morality. This fact becomes evident when one considers slavery in antebellum America. Although it was perfectly legal to own slaves before 1863 , most contemporary Americans believe that slavery was as immoral then as it is now. I would argue, then, that the Tarasoff precedent established a bad law because imposing an obligation on a professional to break her client's confidence fails to promote overall social utility.

This paper began by introducing the dilemma of confidentiality faced by professionals, which forces them to choose between the privacy and well-being of the clients they are trying to help and the public, whose well-being they must also consider. In particular, I have been interested in this dilemma as it pertains to the case of the uncooperative HIV-infected client. Although the threat of HIVtransmission from infected to uninfected parties is harrowing, the evidence is overwhelmingly in favor of supporting an absolute rule of confidentiality between the health care professional and his infected patient. The best course of action the professional can take is to advise his patient to either warn his wife or to alter his own behavior significantly. Reminding him of the terrible complications that often accompany HIV/ AIDS, as well as the effect that his failure to warn may have on his children, might convince him to notify his wife. But first and foremost, the professional's duty is to the client who is seeking assistance from him. Society is better off when we allow professionals to do their jobs correctly, and having 
an absolute rule of confidentiality in the professional setting is the best way to ensure that this occurs.

\section{Notes}

1. Peter C. Appleby, Margaret P. Battin, L. Francis and Peter Y. Windt, Ethical Issues in the Professions. (New Jersey: PrenticeHall, 1989).

2. Partner notification, sometimes called contact tracing, is the process of identifying and notifying past or current sexual or needle-sharing partners of an HIV-infected individual.

3. Tom L. Beauchamp and James F. Childress, Principles of Biomedical Ethics, 2nd ed. (New York: Oxford University Press, 1983).

4. Beauchamp and Childress, Principles of Biomedical Ethics, 2nd ed., 230.

5. Beauchamp and Childress, Principles of Biomedical Ethics, 2nd ed., 282.

6. This case summary and opinion for Tarasoff $v$. University of California come from Alan R. Felthouse, The Psychotherapist's Duty to Warn or Protect. (Illinois: Charles C. Thomas, 1989) and from Vitaly Tarasoff $v$. Regents of the University of California, 17 Cal. 3d 425; 55I P. 2d 334; 1976 Cal. LEXIS 297; 131 Cal. Rptr. 14; 83 A.L.R.3d 1166, 1976. Retrieved December 12, 1999 from LEXIS-NEXIS ACADEMIC UNIVERSE database.

7. Gerald R. Stine, Acquired Immune Deficiency Syndrome: Biological, Medical, Social, and Legal Issues. (New Jersey: Prentice-Hall, 1996).

8. Stine, Acquired Immune Deficiency Syndrome: Biological, Medical, Social, and Legal Issues, cover.

9. Stine, Acquired Immune Deficiency Syndrome: Biological, Medical, Social, and Legal Issues, cover.

10. Stine, Acquired Immune Deficiency Syndrome: Biological, Medical, Social, and Legal Issues.

11. Stine, Acquired Immune Deficiency Syndrome: Biological, Medical, Social, and Legal Issues.

12. Stine, Acquired Inmune Deficiency Syndrome: Biological, Medical, Social, and Legal Issues, 254. 
13. Tom A. Coburn and Kenneth Mayer, "Is It Time to Treat HIV Like All Other STDs?" Washington Post-Health (4 November 1997), 23.

14. Coburn and Mayer, "Is It Time to Treat HIV Like All Other STDs?" 23.

15. Coburn and Mayer, "Is It Time to Treat HIV Like All Other STDs?" 23.

16. Coburn and Mayer, "Is It Time to Treat HIV Like All Other STDs?"

17. J. B. Muth, John J. Potterat, N. E. Spencer and D. E. Woodhouse, "Partner Notification in the Control of Human Immunodeficiency Virus Infection," American Journal of Public Health 79 (1989), 874-76.

18. Muth et al., "Partner Notification in the Control of Human Immunodeficiency Virus Infection."

19. Muth et al., "Partner Notification in the Control of Human Immunodeficiency Virus Infection."

20. Stine, Acquired Immune Deficiency Syndrome: Biological, Medical, Social, and Legal Issues.

21. Franklyn N. Judson, "Partner Notification for HIV Control," Hospital Practice 25 (1990), 63-76.

22. Muth et al., "Partner Notification in the Control of Human Immunodeficiency Virus Infection," 875.

23. Muth et al., "Partner Notification in the Control of Human Immunodeficiency Virus Infection," 875.

24. Muth et al., "Partner Notification in the Control of Human Immunodeficiency Virus Infection," 875-6.

25. Stine, Acquired Immune Deficiency Syndrome: Biological, Medical, Social, and Legal Issues, 256.

26. Stine, Acquired Immune Deficiency Syndrome: Biological, Medical, Social, and Legal Issues.

27. Martin Gunderson, David J. Mayo and Frank S. Rhame, AIDS: Testing and Privacy. (Salt Lake City: University of Utah Press, 1989), 121.

28. Ronald Bayer and Kathleen E. Toomey, "HIV Prevention and the Two Faces of Partner Notification," American Journal of Public Health 82 (1992), 1158-1164. (1159)

29. Bayer and Toomey, "HIV Prevention and the Two Faces of Partner Notification," 1159. 
30. Immanuel Kant, Grounding for the Metaphysics of Morals. (Indiana: Hackett, 1993), 416.

31. Kant, Grounding for the Metaphysics of Morals, 421 .

32. Kant, Grounding for the Metaphysics of Morals, 422.

33. Fred Feldman, "Kantian Ethics," in Ethical Theory: Classical and Contemporary Readings, ed. Louis P. Pojman. (California: Wadsworth, 1989).

34. Feldman, "Kantian Ethics," 264.

35. Kant, Grounding for the Metaphysics of Morals, 422.

36. Kant, Grounding for the Metaphysics of Morals, 422.

37. The best example, in the Groundwork, of a remark made by Kant that might generate this first interpretation of 'contradiction' occurs in section 403, where Kant writes, "Then I immediately become aware that I can indeed will the lie but can not at all will a universal law to lie. For by such a law there would really be no promises at all, since in vain would my willing future actions be professed to other people who would not believe what I professed ..." (emphasis mine).

38. Kant, Grounding for the Metaphysics of Morals, 417.

39. Christine M. Korsgaard, "Kant's Formula of Universal Law," in Creating the Kingdom of Ends. (New York: Cambridge University Press, 1996).

40. Korsgaard, "Kant's Formula of Universal Law," 94.

41. Immanuel Kant, Lectures on Ethics. (New York: Harper \& Row, 1963), 228.

42. Kant, Lectures on Ethics, 228.

43. Kant, Lectures on Ethics, 229.

44. Kant, Grounding for the Metaphysics of Morals, 429.

45. James Rachels, The Elements of Moral Philosophy. (New York: McGraw-Hill, 1993), 121.

46. Rachels, The Elements of Moral Philosophy, 122.

47. Christine M. Korsgaard, "The Right to Lie," in Creating the Kingdom of Ends. (New York: Cambridge University Press, 1996).

48. Korsgaard, "Kant's Formula of Universal Law," 136.

49. John S. Mill, Utilitarianism. (Indiana: Hackett, 1979), 7.

50. David Lyons, Forms and Limits of Utilitarianism. (Oxford: Oxford University Press, 1965), 134. 